\title{
Don Adriano de Armado: a Spanish Character on the English Stage
}

\section{Mélodie Garcia}

\section{Q OpenEdition \\ 1 Journals}

\section{Electronic version}

URL: http://journals.openedition.org/shakespeare/3175

DOI: 10.4000/shakespeare.3175

ISSN: 2271-6424

\section{Publisher}

Société Française Shakespeare

\section{Electronic reference}

Mélodie Garcia, «Don Adriano de Armado: a Spanish Character on the English Stage », Actes des congrès de la Société française Shakespeare [Online], 32 | 2015, Online since 10 March 2015, connection on 24 July 2020. URL : http://journals.openedition.org/shakespeare/3175; DOI : https://doi.org/ 10.4000/shakespeare.3175

This text was automatically generated on 24 July 2020 .

(c) SFS 


\title{
Don Adriano de Armado: a Spanish Character on the English Stage
}

\author{
Mélodie Garcia
}

1 From the onset of the play, Armado jars amidst the other characters: "Don Adriano de Armado, an affected Spanish braggart." ${ }^{1}$ His very long name typographically stands out in the list of characters, just as Armado will stand out in the comedy, taking up a lot of textual, verbal and stage space. Moreover, Don Armado is the only character in the whole Shakespearean corpus to be so heavily defined from the beginning: "an affected Spanish braggart" (my emphasis). ${ }^{2}$ While this twofold definition shapes our expectations as it defines the character, it also contributes to narrow down the role of Armado to that of a fantastical and entertaining jester that will reappear sporadically throughout the play. The colourful Spaniard is syntactically caught between those two words just as any actor's performance and rendering of Armado will tend to be limited by them. In this respect, it is telling that his character should not have drawn much critical attention, ${ }^{3}$ as he is often read according to this somewhat misleading preliminary definition ${ }^{4}$. However, Armado has much more influence and weight in Love's Labour's Lost than what those somewhat reductive characterizations lead us to expect.

2 The first point which is important to understand the character of Armado is the presence of an actual Spaniard at the Elizabethan court who displayed many features reminiscent of Armado: Antonio Pérez, ${ }^{5}$ who was so much like the caricatures of Spaniards that circulated in England at the time that this topical reference enables the dramatist to move effortlessly from the actual contemporary to the ethnotype.

3 Yet, Armado is not merely a referential wink at a contemporary. The very name of the character points out his synecdochic value: Don Adriano de Armado is not just a burlesque of Antonio Pérez - and, through him, of Spaniards -, he works as a synecdoche of his country and is representative of the way Spain was pictured in England after the defeat of the Invincible Armada his name recalls.

4 Those apparently contradictory functions where the character is caught between individuality and generalization trigger a form of imbalance which Shakespeare uses to 
escape both topical references, Pérez and the Spaniard, in order to make a type out of the ethnotype. In a play whose primary concern is language and its abuses, the talkative Don Armado works not so much as a representation of Spain than as a representation of human nature: in Love's Labour's Lost, every character shares common features with Armado.

\section{A parody of Antonio Pérez and of Spaniards}

5 Antonio Pérez was an extravagant figure. He was the trusted Secretary of State to Philip II, but after a complicated string of events involving murder, treason and jousts of influences, he fell out of favour and was imprisoned. He managed to escape and fled to France. He then disembarked in England in April $1593^{6}$. The journey was made in agreement with Henri IV to plead with Elizabeth for an alliance with France which would involve the active participation of England in a naval attack on the Spanish coast. Antonio Pérez was thus a godsend for the war party. However, although Perez was a great political and rhetorical tool, he was also a man whose personality had so many striking aspects that he had become a target for satire, and this is what he is used for in Love's Labour's Lost. From the various sources that have come down to us, he appears as a fantastical man, full of complicated words and sentences. The first depiction made of Armado in the play is striking:

KING. [...] Our court, you know, is haunted, With a refined traveller of Spain,

A man in all the world new fashions planted,

That hath a mint of phrases in his brain.

One who the music of his own vain tongue

Dot ravish like enchanting harmony.

(I.i.160-65)

This appears as the living portrait of the Spaniard, "court" functioning here as a dual reference both to the court of Navarre and to the actual court of England. In the same way, the King addresses the characters on stage through the pronoun "you" while, simultaneously, the actor reaches out to the audience.

Pérez also tended to overestimate the importance of his own fate. In one of his letters, he states: "No debe de haber en la tierra rincón ni escondrijo adonde no haya llegado el sonido de mis persecuciones y aventuras." Similarly, he was inclined to put forward his numerous royal connections, just like Armado exaggerates in the play his intimacy with the King of Navarre: "Sir, the king is a noble gentleman, and my familiar, I do assure ye, very good friend: for what is inward between us, let it pass" (V.i.90-92). The identification of Armado with Pérez is strengthened when Nathaniel and Holofernes meet and describe him as follows: "HOLOFERNES. [...] He is too picked, too spruce, too affected, too odd, as it were, too peregrinate as I may call it" (V.i.12-14). The last adjective, emphasized by its sheer length which weighs down the end of the sentence, is also highlighted by the metadiscursive comment, "as I may call it". This insistence is a solid piece of evidence that Shakespeare caricatures the Spanish minister as it alludes to his favourite pseudonym which he used for his literary works, namely Raphael Peregrino. ${ }^{8}$ In fact, Nathaniel deems Holofernes's newly coined word so memorable that he takes his notebook to record "a most singular and choice epithet" (V.i.16). Such 
emphasis suggests the existence of a topical allusion. But what does Shakespeare make of this association?

7 Pérez was probably not known by the entire audience, since he was confined to a courtly or at least literary public. Consequently, Love's Labour's Lost constantly resorts to the Spaniard's caricature to ridicule both the courtier and Spaniards in general. Indeed, Armado's rhetoric seems to work as a direct echo to both Pérez and Spaniards. Pérez was famous in England for at least two literary works, his Relaciones ${ }^{9}$ (1591) and, maybe even more so because the originals were widely circulated before publication, his Epistles (1603). Both works are marked by a very complicated style, full of hyperboles, enumerations, and the abundant use of parenthetical clauses that recall the English euphuistic style. Spanish literature was then known in England notably through the ornate poems of Góngora. The Spanish poet often resorted to complicated neologisms and a hardly intelligible syntax, often mocked by his contemporaries. If his ornate language was sometimes perceived as worth emulating, it was, when pushed to its limits, regarded as deceitful. Indeed, it was considered to be the consequence of the inherently dissembling nature of the Spanish people, merely using language as an impediment to understanding. The fact that Armado first comes on stage through words with the King's description, but above all through written words, through a letter, thus takes on a new meaning. Indeed, in his letters, his style appears as a direct burlesque of Pérez's writing and of the Spaniards' tricky discourse in general. This is illustrated in Armado's first missive which sets the tune for his use of language and the perception the others have of it throughout the rest of the play:

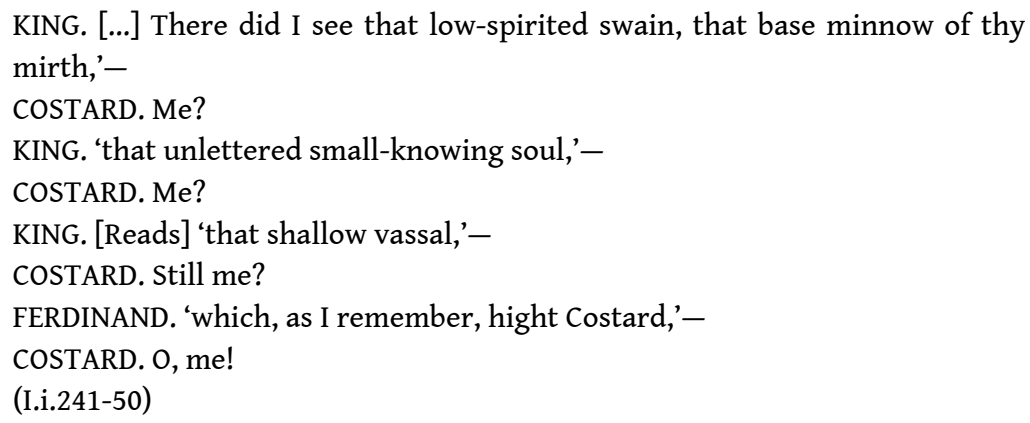

The difficulty Costard has to understand who Armado is writing about echoes the idea that it was always difficult to know what Spaniards were talking about. Periphrasis and delaying strategies are precisely what structures Armado's letter, and they are recurrently emphasised by Costard's interventions that go crescendo. The clown thus reflects here the reader's baffled reaction when discovering Pérez's prose or Góngora's poems.

The alien nature of Armado's language is also conveyed by pronunciation. Characters throughout the play have trouble pronouncing his name, and their constant hesitations emphasize the fact that it is unusual in the English tongue. Dull, for instance, never manages to utter it properly: "Señor Arm- Arm- commends you" (I.i.185). If the English characters have trouble with his Spanish name, Armado similarly distorts the pronunciation of English words:

ARMADO. Chirrah!

HOLOFERNES. Quare chirrah, not sirrah?

(V.i.32-33) 
Although many interpretations were offered to explain this instance of mispronunciation, the most relevant one is that "Chirrah" is the distortion of the word "Sirrah" by an ignorant Spaniard. To support this view, Ungerer quotes a similar device used in Blurt, the Master Constabl ${ }^{10}$. When Lazarillo asks Blurt for permission to be admitted into town, his pronunciation evokes that of Armado: "I do unpenthouse the roof of my carcass, and touch the knee of thy office, in Spanish compliment: I desire to sojourn in your chitty" (I.ii, my emphasis). Here, the scatological play on words creates a comic effect and contributes to caricaturing the Spaniards' way of handling the English tongue.

9 This example shows that caricaturing Pérez consequently often means falling in the tracks of the Spanish ethnotype in general, as Pérez shared many of the characteristics England attributed to Spaniards. By dealing with Pérez, Shakespeare kills two birds with one stone. Those in the audience on whom the reference to Pérez might be lost would still understand the playwright's mocking allusions to Catholic Spain. However, by naming his character Armado, Shakespeare enables him to be more than just a jester aimed at making the audience smile. Indeed, Armado cannot be reduced to Pérez, or to a set of supposedly Spanish characteristic features: he also embodies Spain as a nation.

\section{From "traveller" (I.i.161) to "empire" (I.i.167): Armado as a synecdoche of Spain}

From the very beginning, Armado is attributed a number of ambiguous features closely linking him to Spain ${ }^{11}$. Let us quote the first reference to him again:

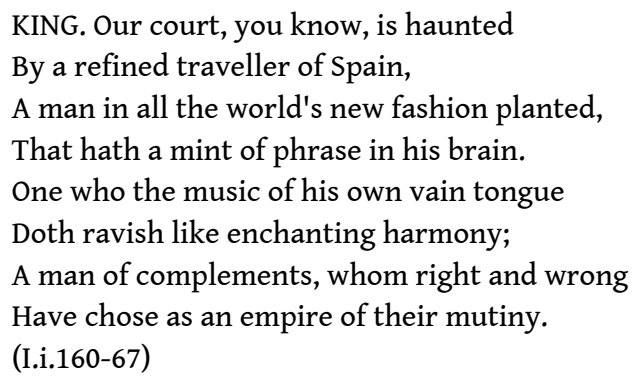

11 The "New World", as well as the words "plantation" and "umpire" are obvious allusions to Spain, so much so that Don Armado is presented here as a miniature of his country, or a mini "umpire", so to speak. The fact that a character representing Spain should be called Armado hints at the specific view taken on Spain. This name obviously refers to the Armada and would have caught the attention of any English man or woman in the audience. The reference would have been all the more obvious that the alteration we easily detect today, from Armada to Armado, would not have been perceived as such by an English audience, as the unstressed vowel of the suffix "-ada" was easily rounded to the more homely sound of an "o" ${ }^{2}$. For those who would have missed the reference, the King makes it even more explicit a moment later. Indeed, less than twenty lines after having clearly linked Armado with Spain and its power as an empire, the King designates him as "the magnificent Armado" (I.i.188), a phrase commonly used to refer to the Spanish fleet that could not have gone unnoticed. However, in naming his character so, Shakespeare had more in mind than just pointing out to the audience that 
his character was Spanish. It was above all a way to reduce England's arch-enemy to one of its most stinging failures the better to ridicule it.

The Armada episode (1588) had an enormous impact in England. The impressive Spanish fleet, helped by the experience it had gathered in the seas of the New World and preceded by all the horrors circulated by what was termed afterwards the Black Legend ${ }^{13}$ was defeated by the tiny English Navy. The explosion of joy and, conversely, of nasty satire, can be easily measured if one considers the number of pamphlets and general references to the Armada in the aftermath of its failure. The unexpected victory, considering the unequal balance of forces, was not only explained by the Will of God, protecting the true faith, that is to say England's, but above all by the Spaniards' supposed cowardice. According to historian William Maltby:

The Armada added two vices hitherto unthought of by earlier propagandists: cowardice and incompetence. At first sight, it seems unaccountable since by minimizing the fighting abilities of the Spaniards, the writers were at the same time diminishing the glory of those who had defeated them. But the Armada was obviously not the end of the conflict with Spain and the English people, brought up on tales of Spanish prowess, needed to be reassured that the failure of the Armada was not an isolated incident but a symbol of Spanish decay. ${ }^{14}$

14 This is precisely what Armado stands for: Spain is no longer a powerful enemy that has to be feared, it can at last be mocked. One of the many instances of Armado's ridicule backs this interpretation since it directly refers to the then proverbial cowardice of Spaniards, and thus associates the character with the failure of the Armada. This link becomes especially telling when studied alongside a pamphlet published at the time.

On Pérez's arrival in England, a pamphlet entitled A Fig for the Spaniard was penned. It briefly related Pérez's vicissitudes at the hands of the obviously incredibly cruel Philip II and was meant to fuel national anti-Spaniard hatred. One passage is worth mentioning here since it tells the anecdote of a brawl occurring between a Portuguese and a Spaniard:

A Portingal gentleman walking in the Roceio of Lisbon espied a base Castilion of such proud and presumptuous demenor, so fantasticall in his attire, loftie in his looks, and slow in his pace (as though he had bin treading of measures) could no longer bear him but bearded him and insulted him. ${ }^{15}$

The passage clearly echoes that of Armado, as both descriptions tap into the same ethnotype. A description follows of others Spaniards (who were revelling at the same moment in a nearby brothel, so that the picture of Spanish vices should be complete) coming to their friend's rescue, but eventually taking to their heels and fleeing. The end of the anecdote chimes with the aborted fight between Costard and Armado, a fight which never takes place because of the latter's cowardice:

ARMADO. Gentlemen and soldiers, pardon me; I will not combat in my shirt. DUMAINE. You may not deny it: Pompey hath made the challenge.

ARMADO. Sweet bloods, I both may and will.

BIRON [BEROWNE]. What reason have you for't?

ARMADO. The naked truth of it is, I have no shirt; I go woolward for penance.

BOYET. True, and it was enjoined him in Rome for want of linen [...]

(V.ii.697-70) 
The reference to Catholic Rome strengthens the alienness of Armado precisely when he is ridiculed for his cowardice. Just like the Castilians of the pamphlet, Armado first shows "extreme heat of choler" 16 before finding a way out when he realises his opponent is actually willing to see their quarrel through. Both the play and the pamphlet re-enact the fall of the enemy they used to fear through apparently meaningless anecdotes. In Shakespeare's comedy, the "Nemean lion's roar" (IV.i.87) no longer frightens England but excites her laughter ${ }^{17}$.

\section{An embodiment of "the great feast of language" (V.i. 36-37)}

17 However, if Armado works as the synecdoche of his country, the characteristics attributed to him are actually common to most of the characters in the Love's Labour's Lost. In a play whose utmost concern is language and its uses, Armado's intricate syntax and complicated words are as much a caricature of Pérez and the Spaniards as of the style of almost every other character. This reversal, from ethnotype to type, is best seen in the Princess's reaction. Her response to Armado's refined language stresses his alienness while the parallel dialogue between Armado and the King undermines it:

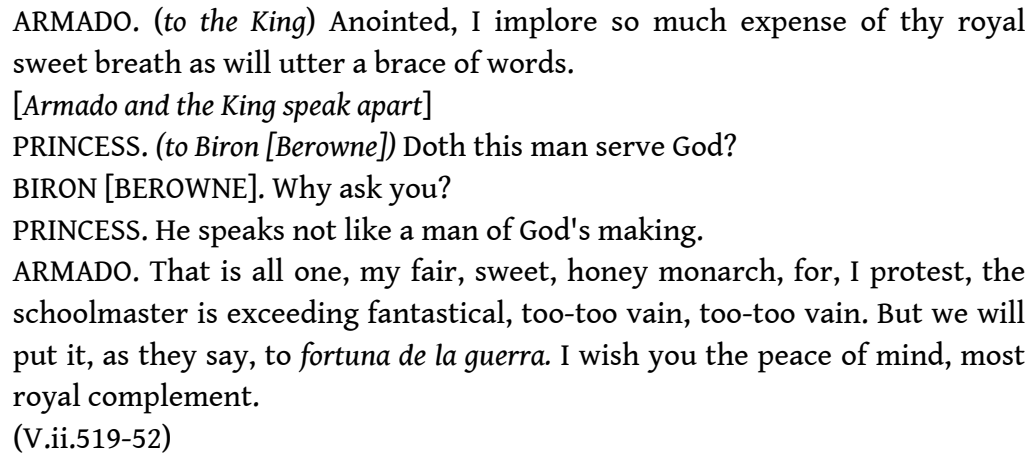

Ironically, the Princess mentions the intricate and pretentious speech of Armado precisely when the latter is complaining about Holofernes's vanity and the way the schoolmaster has handled the embedded play they are about to perform. Moreover, he ends his aside with the King on a Spanish phrase: "we will put it, as they say, to fortuna de la guerra". The apposition "as they say" distanciates Armado from the rest of the Spaniards, thereby diminishing his own foreigness. Moreover, he is the one to put an end to the conversation with the King, just as he is the one who calls for silence when tongues go mad during his performing of Mars exclaiming: "Peace!" (5.2.643) and trying to discipline the lords and to check their unreined recourse to language ${ }^{18}$.

Similarly, when Holofernes describes Armado, he strikingly refers to a literary type, and not to an ethnotype: "Novi hominum tanquam te. His humour is lofty, his discourse peremptory, his tongue filed, his eye ambitious, his gait majestical, and his general behavior vain, ridiculous, and thrasonical" (V.i.9-12). Holofernes starts by drawing a parallel between Armado and Nathaniel ("I know the man as well as I know you"), thus suppressing Armado's alienness by confusing both identities. He then ends his sentence with the reference to a well-known dramatic type, the braggart ${ }^{19}$. This reference turns Armado into a more universal character than just a Spaniard. Even though he is characterized as a Spaniard, he has much more in common with the rest of the 
characters that they would like to admit. For instance, Armado's soliloquy in I.ii evokes and announces all the written production the lords read to the audience: "Assist me, some extemporal god of rhyme, for I am sure I shall turn sonnet. Devise wit, write pen, for I am for whole volumes, in folio" (I.ii.174-76). This reference to the play's materiality highlights the metatheatrical resonance of Armado's statement and proves that he is not so much a representation of Pérez or Spain as a mirror to the other characters and a key to the play ${ }^{20}$. He seems to be present on stage even when he is not physically there. He is indeed present through words, either those of his own letters or those of the other characters when they refer to him. More generally speaking, Armado turns out to be a living comment on the abuses of language so frequent in the comedy: confusing dialogues, messages that never reaches their intended audience, or pointless discourses. On top of that, Armado utters the final lines of the play, which underlines his conclusive function: "The words of Mercury are harsh after the songs of Apollo. You that way, we this way" (V.ii.913-14). Significantly, his closing observation still deals with "words", emphasizing once last time, as the play draws to its end, his special connection to language.

His handling of language, at first strongly attributed to his Spanish origins, thus makes Armado a synecdoche not so much of Spain, but of the play as well. The numerous echoes and strategies of substitution between the various groups of men in the play have been much studied. Holofernes and Nathaniel, the pedant and the curate, give the key to the lords' use of language by caricaturing them. Armado works the same way, as his foreignness brings some comic elements to the general reflection on language while being cathartically ridiculous for an English audience galvanized by the memory of the Great Armada.

\title{
Conclusion: Foreign men and pretended foreigners in Love's Labour's Lost
}

\author{
BIRON [BEROWNE]. [...] in the afternoon \\ We will with some strange pastime solace them, \\ Such as the shortness of the time can shape; \\ For revels, dances, masks and merry hours \\ Forerun fair Love, strewing her way with flowers. \\ (IV.iii.352-56)
}

The pastime devised by the men to entertain the ladies is indeed "strange", as they will dress themselves as strangers, "like Moscovites or Russians" (V.ii.122). However, their masque will turn out a failure since each man will court the wrong lady and end up in perjury. This scene summarizes the abuses of languages recurrent in the play: the messages are misdelivered, once again, and love oaths are broken as the lords broke their promise to fast and study at the beginning of the play. Just like Armado, the Russians crystallize the anxieties about language that run throughout the play. Moreover, Rosaline's comment echoes the Princess's response to Armado evoked before and strengthens the parallel between the various foreigners in the comedy ${ }^{21}$ :

ROSALINE. What would these strangers? know their minds, Boyet.

If they do speak our language, 'tis our will

That some plain man recount their purposes. 
Know what they would.

(V.ii.174-77)

21 The emphasis on a possible communication problem - "if they do speak our language" (my emphasis) - knowing that the ladies are fully aware of who the "Russians" really are, is a key to explaining the gap between the different uses of language in the play. Men and women do not speak the same language, just as the pedants and the peasants display very distinct linguistic identities, and (so-called) foreigners are a way to embody and crystallize this anxiety which has, in fine, nothing to do with foreign tongues. The linguistic problem that dooms most of the dialogues in the play is not that the characters speak different languages, but that they fail to resort to "plain" words.

The embedded play within the play also serves as a metatheatrical comment on Armado: the lords are playing foreigners just as the actor playing Armado is merely acting like a Spaniard. Through the masquerade, the King and his men seem to literalise the fact that they are themselves Armadoes: they are Russians instead of Spaniards, but they are acting out stereotypes all the same.

Shakespeare relies on the well-known ethnotype of the Spaniard while also referring to an actual Spanish courtier in order to point out a defective use of language common to all the characters in the play. Knowing that his audience would be alert to anything Spanish, especially if named after the Great Armada, the playwright seems to use the attention Armado will inevitably draw to highlight a human feature all characters share (i.e. the difficulty to communicate and to apprehend the true function of language), handing to everyone, both on stage and out stage, a magnifying mirror.

\section{NOTES}

1. All references to Love's Labour's Lost are drawn from The Complete Works, eds. John Jowett, William Montgomery, Stanley Wells and Gary Taylor, $2^{\text {nd }}$ edition, Oxford, OUP, 2005.

2. The Complete Works, op. cit., p. 308. Barnardine, the "dissolute condemned prisoner" of Measure for Measure is attributed heavy and limiting characteristics as well. However, the features he is ascribed are arguably less subjective than those of Armado, especially as far as the adjective "condemned" is concerned.

3. Critical studies do exist, though. See for instance Daniel Buchner, "Don Armado and the Commedia dell'Arte," Studies in Philology, 37, 1940, p. 201-24; "Don Armado as Gallant," Revue Anglo-Américaine 13, 1935, p. 18-28. Francesco Cordasco, Don Adriano de Armado of Love's Labour's Lost, Bologne, Facolta di Lettere e Filosofia, La Universita, 1950. Lynne Magnusson. “'To gase so much at the fine stranger': Armado and the Politics of English in Love's Labour's Lost" in Shakespeare and the Culture of Performance, eds. Paul Yachnin and Patricia Badir, Aldershot: Ashgate, 2008, p. 53-68. Gustav Ungerer, Anglo-Spanish Relations in Tudor Literature, Madrid, Madrid: Schweitzer, 1956.

4. There is no list of dramatic personae in either the 1598 Quarto or the 1623 Folio and the description of Armado varies with each edition. However, he is always described through an epithet which underlines his eccentricity or braggartism. 
5. This contemporary reference is very convincingly elucidated by Gustav Ungerer in the third chapter of his book Anglo-Spanish relations in Tudor literature, op. cit.

6. For an extensive account of Pérez's life, see Gregorio Marañon, Antonio Pérez: El Hombre, El Drama, La Época, Buenos Aires: Espasa-Calpe Argentina, 1948.

7. Julia Fitzmaurice-Kelly, Antonio Pérez, Oxford: Oxford UP, 1922, p.1. "There is no place on earth where the tale of my persecutions and adventures remain unknown" (my translation)

8. The London edition of Pérez' famous book, the Relaciones, as well as a later treatise were both published under this name.

9. The Relaciones were first published in Spanish by Richard Field. They created a great sensation at the Elizabeth's court and a copy was presented to Sidney. It was translated into English in 1591. A Latin translation was penned by John de Cárdenas. It was never published however as, according to Ungerer, "by this time the Pilgrim's star was already dwindling away in England", op. cit., p. 94-95.

10. The Works of Thomas Middleton, Ed. A. H. Bulen, New York: AMS Press, 1964.

11. The same quotation illustrates the reference both to Pérez and to Spain (see above) which shows how intricate the various levels of referentiality are and how easily the play moves from one to another.

12. Both forms, Armado and Armada, are indeed found in contemporary documents.

13. See the pioneering work of William Maltby, The Black Legend in England: The Development of Anti-Spanish Sentiment, 1558-1660, Durham: Duke University Press, 1971.

14. William Maltby, The Black Legend, op. cit., p. 77. Historians have been arguing over the reason explaining the English victory but I am dealing here not with the correct historical set of reasons, but with the actual English perception of this victory.

15. G B. A Fig for the Spaniard, London, John Wolfe, 1591, C2.

16. Ibid., C3.

17. The same process can be observed when Armado chooses to play Hector in the masque at the end of the play. His pompous announcement is immediately debunked by the lords, just as the rest of his bombastic interventions are generally undercut throughout the play. The exchange accentuates the characteristics of Armado's inflated sense of self - he is playing Hector, nothing less - and the ridicule he is exposed to because of it.

18. During the conference, Sophie Lemercier-Goddard pointed out that, at the end of the play, the audience is told that Armado will "hold the plough for her [Jaquenetta's] sweet love three years" (V.ii.870). We are thus eventually presented with an image of the perfect Englishman.

19. The adjective "thrasonical" comes from the braggart soldier in Terence's Eunuchus. It evokes the well-known dramatic type of the miles glorious inspired by Plautus.

20. In this respect, it would probably prove fruitful to suggest a comparison between Barnardine in Measure for Measure and Armado. The hyper definition of both characters (see footnote 2) indeed takes on a broader significance as far as the play is concerned: in Love's Labour's Lost, Armado embodies the reflexion on language all the characters contribute to, while in Measure for Measure, Barnardine crystallizes what is at stake in the play in terms of vice and justice's response to it.

21. Armado is also compared to the Monarcho, a delusional Italian living at the court of England and entertaining the Elizabethans with his fantasies as he pretended to be a powerful emperor (4.1.92). This topical allusion seems to link Armado with the Mediterranean world in general, and not just with Spain. I would argue however that it contributes to reinforcing the characterization of Armado as alien without affecting his inherent Spanishness. Indeed, Italy and Spain shared in the eyes of the Elizabethan not only a political and religious connection, but also a set of common features in keeping with the theory of humours and climates which corresponds precisely to the stereotype Armando acts out: braggartism, quick temper. 


\section{ABSTRACTS}

In this paper, I consider the Spanish character staged in Love's Labour's Lost, Don Adriano de Armado, to study the very specific way Shakespeare uses ethnotypes. To do so, I will first recall a possible reference for Armado: Antonio Pérez was a contemporary at the court of England and Shakespeare uses this topical reference to fashion his own ethnotype representing not just a Spaniard, but Spaniards in general. Shakespeare then relies on this ethnotype to stage Spain itself through a synecdochic shift and to present his contemporaries with a cathartic representation of England's most feared enemy. I will then argue that Shakespeare creates an ethnotype only the better to deconstruct its alienness by showing that everyone, both on stage and out stage, is his or her own version of Don Armado.

Cet article se propose d'étudier le personnage de l'Espagnol mis en scène dans Peines d'amour perdues, Don Adriano de Armado, afin d'analyser la manière très spécifique dont Shakespeare utilise les ethnotypes. Pour ce faire, je commencerai par élucider une possible référence à un contemporain : Antonio Pérez était un Espagnol présent à la cour d'Angleterre, et le dramaturge semble utiliser cette référence pour construire un ethnotype lui permettant de caricaturer non un Espagnol en particulier, mais l'Espagnol en général. Grâce à la création d'une caricature de l'Espagnol, il met ensuite en scène, par un procédé synecdotique illustré dans le nom d'Armado, une représentation de l'Espagne elle-même. Cette mise en scène se fait sur un mode cathartique pour ses contemporains particulièrement marqués par le conflit anglo-espagnol. Je m'attacherai ensuite à démontrer que, si Shakespeare construit un ethnotype renvoyant à l'Espagne, c'est pour mieux le déconstruire au fil de la pièce en remettant en question son étrangeté : sur la scène de Peines d'Amour Perdues, chaque personnage est un Armado en puissance.

\section{INDEX}

Mots-clés: Peines d'amour perdues, Pérez Antonio, Espagne, Armada, stéréotype, ethnotype, représentation, étranger

Keywords: Love's Labour's Lost, Pérez Antonio, Spain, stereotype, ethnotype, representation, alien

\section{AUTHOR}

\section{MÉLODIE GARCIA}

Université Paris-Sorbonne 